\title{
Kalkınma ve Yatırım Bankalarının CAMELS Analizi Yöntemiyle Finansal Performanslarının Değerlendirilmesi \\ (Evaluating Financial Performances of Development and Investment Banks Through Camels Analysis)
}

\section{Ersan ÖZGÜR iD a}

a Türkiye Büyük Millet Meclisi Kamu Denetçiliği Kurumu, Ankara, Türkiye. ersanozgur@yahoo.com

\begin{tabular}{|c|c|}
\hline MAKALE BİLGİSİ & ÖZET \\
\hline $\begin{array}{l}\text { Anahtar Kelimeler: } \\
\text { CAMELS Analizi } \\
\text { Kalkınma ve Yatırım Bankaları } \\
\text { Finansal Denetim } \\
\text { Finansal Oranlar }\end{array}$ & $\begin{array}{l}\text { Amaç - Kalkınma ve yatırım bankaları gelişmekte olan ülkelerde ekonominin büyümesi için } \\
\text { yatırımcılara kaynak ve proje desteği sağlamak amacıyla kurulmaktadır. Bu bankalar yabancı } \\
\text { sermayenin ülkeye girişini kolaylaştırmakta ve böylece ülkeye yatırım yapılması konusunda destek } \\
\text { sağlamaktadır. Bankalar ayrıca uygulanmasına karar verilen projelere ilişkin verimlilik ve kârlılık } \\
\text { yönünden değerlendirmelerde bulunarak teknik destek sağlamaktadır. Kalkınma bankaları ve yatırım } \\
\text { bankaları birbirlerini tamamlayan bir özellikte olup, Türkiye'de kalkınma bankacılığı ve yatırım } \\
\text { bankacılığı aynı banka grubu içinde değerlendirilmektedir. Türkiye'de kalkınma ve yatırım } \\
\text { bankalarının } 2020 \text { yılı itibariyle sermaye yeterliliği oranı \%25.6, ortalama özkaynak kârlılığı ise } 12.5 \\
\text { seviyesindedir. Ekonomide önemli işlevlere sahip bankaların performanslarının ölçülmesi ve } \\
\text { denetlenmesi gerekli görülmektedir. Böylece olumsuz finansal veriye sahip bankaların önceden } \\
\text { belirlenmesi sağlanmaktadır }\end{array}$ \\
\hline
\end{tabular}

Kabul Tarihi 10 Ekim 2021

Makale Kategorisi:

Araştırma Makalesi
Yöntem- Gelişmiş ülkelerde uzaktan gözetim konusunda uygulanan yöntemlerden birisi de CAMELS analizidir. Bu çalışmada, 2009-2019 yılları arasında faaliyette bulunan 3'ü kamusal sermayeli, 6'sı özel sermayeli olmak üzere toplamda 9 kalkınma ve yatırım bankası örneklem olarak kullanılmıştır. Araştırma kapsamındaki bankalara ait 6 bileşen kapsamında belirlenen 21 mali oran ile CAMELS analizi gerçekleştirilmiştir.

Bulgular - Araştırmanın sonucunda, CAMELS gösterge değerleri yönünden kalkınma ve yatırım bankalarının aldığı pozitif ve negatif değerler ile yıllar itibariyle eğilimleri tespit edilmiştir. Alınan sonuçlar banka yetkililerine hem yol göstermekte hem de gelecek yönelimli perspektiflerinde ne tür bir tutum ve davranış içinde olmaları gerektiği hususunda belirli ipuçları vermektedir.

Tartıșma - CAMELS derecelendirme yöntemi kullanılmak suretiyle bileșenlerde farklı finansal oranlar kullanılarak ilerleyen süreçte araştırmacılar tarafından değişik uygulamalar yapılabilir. Ayrıca Türkiye için önemli bir konuma sahip olan kalkınma ve yatırım bankalarının farklı yöntemlerle araştırılabileceği öngörülmektedir.

\section{ARTICLE INFO}

ABSTRACT

\section{Keywords:}

CAMELS Analysis

Development and Investment

Banks

Financial Audit

Financial Ratios

Received 8 July 2021

Revised 30 September 2021

Accepted 10 October 2021

Article Classification:

Research Article

Purpose - Development and investment banks are established to provide resources and project support to investors for growth of the economy in developing countries. These banks facilitate foreign capital inflow into the country, thus supporting investments to be made in the country. Banks also provide technical support by evaluating the efficiency and profitability of the projects decided to be implemented. Development banks and investment banks complement each other, and development banking and investment banking are considered within the same group in Turkey. The capital adequacy ratio of development and investment banks in Turkey is $25.6 \%$ and the average return on equity is $12.5 \%$ by 2020 . It is considered necessary to measure and audit the performances of banks with important functions in the economy. In this way, it is ensured that banks with negative financial data are identified in advance.

Design/Method/Approach - One of the methods adopted in remote surveillance in developed countries is CAMELS analysis. In this study, a total of 9 development and investment banks including 3 public and 6 private banks operating between 2009-2019 were selected as the sample. CAMELS analysis was conducted with 21 financial ratios determined within the context of 6 components for the banks in the study.

Findings - The study results revealed the positive and negative values of the development and investment banks regarding CAMELS indicator values together with their trends by years. The results

\section{Önerilen Atıf/Suggested Citation}

Özgür, E. 2021). Kalkınma ve Yatırım Bankalarının CAMELS Analizi Yöntemiyle Finansal Performanslarının Değerlendirilmesi, İşletme Araştırmaları Dergisi, 13 (4), 3206-3221. 
not only guide bank officials but also give certain clues about what kind of an attitude and behavior they should maintain in their future-oriented perspectives.

Discussion - By using the CAMELS rating method, different applications can be made by the researchers in the future by using different financial ratios in the components. In addition, it is foreseen that development and investment banks, which have an important position for Turkey, can be researched with different methods.

\section{Giriş}

Kalkınma ve yatırım bankalarının kuruluş amaçları gelişmekte olan ülkelerde yatırım ve proje desteği sağlamak ve yatırım yapmak isteyen yabancı yatırımcıların fonlarını ülkeye çekebilmektir. Gerçekleştirilecek projelerle verimliliği, kârlılığı ve kalkınmayı sürdürmeyi hedefleyen bu bankalar yatırım aşamasında proje yönetimi ve finansman alanında teknik destek sağlamaktadır. Kalkınma ve yatırım bankaları birbirini tamamlayan iki bankacılık türüdür. Hukuki yapıları ile birbirine benzerlik göstermektedirler. Ancak bu bankaların işlevsel yönden amaçları, faaliyet konuları ve yaklaşımları birbirinden farklılaşmaktadır. Kalkınma bankaları, genel olarak gelişmekte olan ülkelerde sermaye ve girişim faktörlerini desteklemekte ve geliştirmektedir. Kaynakların kalkınma hedefleri doğrultusunda fon ihtiyacı olan birimlere aktarılması ve ayrıca gerekli teknik yardımların da sağlanması yönünden kalkınmaya katkı sağlamaktadırlar. Yatırım bankaları ise, gelişmiş ülkelerde atıl fonu bulunan ve yatırım yapmak isteyen kurumsal yatırımcılara, fonlarını değerlendirmelerinde aracılık ve danışmanlık işlevi görmektedir. Bu bankalar işletmelerin finansmanı için doğrudan kredi vermemekte ancak işletmelerin orta ve uzun vadeli fon ihtiyacını karşılamaktadır. Kalkınma ve Yatırım bankaları işlevsel açıdan benzerlik göstermekte olup, uzun vadeli fon sağlama alanında faaliyette bulunmaktadırlar (Şenel ve Şekercioğlu, 2019:566).

Ekonomi ve endüstri ile ilgili gelişmeye katkı sağlayan kalkınma ve yatırım bankaları, önemli stratejik yatırım alanlarını belirlemenin yanı sıra faaliyet gösteren işletmelerin kapasitelerini artırmalarına ve yenilikçi projelerine yeni yatırım yapmaları yönünde teknik, örgütsel ve mali açıdan destek sağlamaktadırlar. Bu bankalar yerel kaynaklarla birlikte uluslararası piyasadan elde ettikleri kaynakları değerli projelere yönlendirmek suretiyle ülke ekonomisinin gelişmesine, istihdam alanlarının genişlemesine ve toplumsal refahın artmasına imkân sağlamaktadırlar (Karahanoğlu, 2017:168)

Kalkınma ve yatırım bankaları genel ekonomi için önemli bir konuma sahiptir. Bu bankaların performansı ile finansal durumu genel ekonomiye etkileri yönünden değerlendirilmesi gerekmektedir. Modern bankacılıkta yerinde denetim uygulamaları ile bankaların mevcut finansal durumları ile ilgili bilgiler elde edilmektedir. Yerinde denetim ile bankanın finansal performansı, kredilerinin yapısı, sermayenin yeterliliği, yöneticilerin kabiliyeti ve tecrübesi hakkında bilgilere ulaşılabilmektedir. Bu denetimlerle elde edilen bilgiler ışığında bankaların başarısızlıkları tahmin edilmektedir. Finansal raporlar sıklıkla güncellenmekle birlikte piyasa verileri ile kredi ve banka operasyonları hususunda bütün bilgileri kapsayamayabilir. Yerinde denetim sayesinde bankanın performans durumu ayrıntılı bir şekilde görülebilmektedir. Bankaların mali durumu ve performansı finansal sistem için önemlidir. Ancak, bankaların yerinde denetimi yüksek maliyet ve yoğun emek gerektirdiği dolayısıyla uzaktan kontrolleri ve denetimlerinin yapılması daha uygun görülmektedir (Şen ve Solak, 2011:52).

Bankaların uzaktan denetimi ile mali durumları ve performansları olumsuz yönde gelişen bankaların önceden tespit edilmesi, banka yöneticileri ve piyasa aktörleri açısından gerekli görülmektedir. Gelişmiş ülkelerde uzaktan gözetim ile ilgili kullanılan yöntemlerden birisi olan CAMELS derecelendirme sistemi, bankaların mali yapılarında bozulma olup olmadığı hususunda tahminde bulunmak ve mali yönden sıkıntı yaşayan bankaları belirlemek için geliştirilmiştir. Farklı ülkelerde değişik şekillerde uygulanmakla birlikte bu yöntem ile amaç bankaların sağlamlığı hakkında ölçüm gerçekleştirmektir. Finansal sistemin önemli unsurlarından olan bankaların istikrarlı ve güvenli çalışmalarını sağlamak üzere uzaktan gözetim ve yerinde denetim yapmak için kullanılan bu performans uygulamasında " $\mathrm{C}$ ", sermaye yeterliliğini (Capital Adequacy); "A", aktif kalitesini (Asset Quality); “M", yönetim yeterliliğini (Management Adequacy); "E”, kazanç durumunu (Earnings); "L" likiditeyi (Liquidity); "S" ise piyasa risklerine duyarlılığı (Sensitivity to Market Risks) ifade etmektedir (Şen ve Solak, 2011:52).

Kalkınma ve yatırım bankaları genel ekonominin gelişmesi, üretim ve istihdamın artması, işletmelerde rekabetçi gücünün gelişmesi için kaynak sağlayan yapılar olarak finansal piyasaların değerli kurumlarıdır. Bu 


\section{E. Özgür 13/4 (2021) 3206-3221}

doğrultuda finansal piyasaların ve özellikle de bankacılık sektörünün yapısının, büyüklüğünün ve sağlamlığının gerçekleştirilmesi genel ekonomi açısından önemli görülmektedir. Bankaların performansının belirlenmesi ve sağlamlığı veya zayıflığının tespit edilmesinde kullanılan sistemlerden birisi de CAMELS analizi olup, risk denetiminde kullanılan, banka içi ve dışının kontrolü ile erken bir uyarı sistemi olarak değerlendirilebilir (Ege vd. 2015:110)

Türkiye'de kalkınma bankacılığı ve yatırım bankacılığı aynı banka grubu çerçevesinde değerlendirilerek sermayesi yönünden; kamu sermayeli, özel sermayeli ve yabancı sermayeli olarak sinıflandırılmaktadır. Kalkınma ve yatırım bankaları ile ilgili olarak 2020 yılı itibariyle sermaye yeterliliği oranı \%25,6 düzeyinde, ortalama özkaynak karlılığı 12,5 düzeyindedir. Bankacılık sektöründe çalışanların \%2,5'i kalkınma ve yatırım bankaları tarafından istihdam edilmektedir (TBB, 2021). Türkiye finans sisteminde önemli bir konuma sahip bulunan kalkınma ve yatırım bankalarının performansının belirlenmesi için CAMELS analizi uygulamanın faydalı olacağı değerlendirilmiştir. Türkiye' de kalkınma ve yatırım bankacılığının mevcut durumu Tablo 1.'de gösterilmektedir.

Tablo 1. Kalkınma ve Yatırım Bankası Mevcut Durumu (2019-2020)

\begin{tabular}{|c|c|c|}
\hline & $\mathbf{2 0 1 9}$ & $\mathbf{2 0 2 0}$ \\
\hline Banka sayısı & 13 & 14 \\
\hline Şube sayısı & 62 & 64 \\
\hline İstihdam & 5000 & 5000 \\
\hline
\end{tabular}

Kaynak: TBB, 2021

Kalkınma ve yatırım bankaları bankacılık sektöründe faaliyette bulunan diğer banka grupları ile karşılaştırıldığında sektörden aldığı pay 2020 yılı itibariyle Tablo 2.'de verilmektedir.

Tablo 2. Banka Gruplarının Sektör Payları (2020, yüzde)

\begin{tabular}{|c|l|l|l|}
\hline & Aktifler & Krediler & Mevduat \\
\hline Mevduat & 87 & 86 & 91 \\
\hline Kamu & 38 & 39 & 41 \\
\hline Özel & 28 & 27 & 30 \\
\hline Yabancı & 20 & 20 & 20 \\
\hline Kalkınma ve Yatırım Bankası & $\mathbf{6}$ & 7 & $\mathbf{0}$ \\
\hline Katılım bankası & 7 & 7 & 9 \\
\hline Sektör & 100 & 100 & 100 \\
\hline
\end{tabular}

Kaynak: TBB, 2021

Tablolarda belirtilen verilerden anlaşıldığı üzere kalkınma ve yatırım bankalarının Türkiye'de önemli bir konuma sahip olduğunu ve gelişmesini sürdürdüğünü göstermektedir.

Bu çalışmada, ilk olarak bankacılık sektöründe yapılmış CAMELS analizi konusu ile ilgili literatür taraması bilgisine yer verilecek, ardında araştırmanın amacı ve kapsamına değinilecek, daha sonra araştırmanın yöntemi CAMELS analizi ile uygulamanın modeline ilişkin bilgiler verilecek olup, son olarak araştırmanın uygulaması gerçekleştirilerek elde edilen bulgular değerlendirilecektir. 


\section{Literatür İncelemesi}

Literatürde, bankacılık sektörü için yapılmış CAMELS analizi ile ilgili çalışmalardan bazıları aşağıda özetlenmiştir.

Çinko ve Avcı (2008) Türk Ticari Bankacılık sistemi için CAMELS dereceleme sisteminin uygulanabilirliğini değerlendirdikleri çalışmalarında toplamda 44 banka için 1996-2000 yıllarını kapsayan verileri kullanarak analiz gerçekleştirmişlerdir. Analize dahil bankalardan 19 banka 1997 - 2001 yılları arasında TMSF'ye devredilmiştir. Elde edilen bulgulara göre bir bankanın TMSF'ye devrinin temsili CAMELS oranları ile yapılan analiz neticesinde tahmin edilmesinin mümkün olmadığ 1 şeklindedir. Şöyle ki, TMSF'ye devredilen bazı bankaların faaliyete devam eden bankalara göre daha başarılı CAMELS skoru aldığı yönündedir.

Arıçelik (2010) çalışmasında 2002-2009 yılları arasında faaliyette bulunan ticari bankaların performansını CAMELS analizi yöntemiyle değerlendirmiş olup, CAMELS bileşenleri yönünden yapılan değerlendirmede 2002-2009 döneminde en çok artan bileşenlerin; aktif kalitesi, yönetim kalitesi ve likidite bileşenleri olduğu, piyasa riskine duyarlılık bileşeninde ise önemli bir değişme görülmediği, toplam CAMELS puanı yönünden 7 bankanın CAMELS puanlarında iyileşme söz konusu iken 6 bankanın puanında gerileme görüldüğü tespit edilmiştir.

Şen ve Solak (2011) çalışmalarında 1995-2008 yıllarını kapsayan dönemde mevduat bankalarının kırılganlığında meydana gelen değişimi CAMELS yöntemi kullanarak analiz etmişlerdir. Altı ana bileşen ile ilgili 24 finansal oran kullanılarak gerçekleştirilen çalışmada sonuç olarak; kamu, özel ve yabancı sermayeli bankalar sınıflandırması açısından kamu bankalarının 2001 krizi öncesinde başka bankalara göre çok kötü bir performansa sahip oldukları kriz sonrasında ise performanslarında önemli derecede iyileşme yaşandığı, yabancı sermayeli bankalar sermaye yeterliliği, kârlılık ve likidite kalitesi yönünden küresel krizde başka banka gruplarına göre daha kötü bir performans sergilediği, özel sermayeli bankaların tüm dönemlerde sektör ortalamasının üzerinde bir performansa sahip olduğu tespit edilmiştir.

Kandemir ve Arıcı (2013), Türkiye'de faaliyette bulunan mevduat bankalarının mülkiyet yapısı itibariyle gruplandırmak suretiyle 2001-2010 yılları arasındaki performanslarını banka grubu yönünden karşılaştırmalı analizini gerçekleştirmişlerdir. Uygulamada CAMELS Performans Değerleme Modeli kullanılmıştır. Yapılan analizin sonucunda mevduat bankalarının sermaye yeterlilik ve likidite oranlarının yüksek olduğu, yabancı sermayeli mevduat bankalarının aktif kalitesi ve yönetim kalitesi açısından diğer banka gruplarına göre en iyi performansa sahip olduğu ayrıca piyasa risklerine karşı diğer gruplara göre daha duyarlı olduğu belirlenmiştir.

Ege vd. (2015), çalışmalarında, kamu, özel ve yabancı sermayeli mevduat bankalarının 2002-2010 dönemine ilişkin verileri ile performans ölçümü yapmak üzere CAMELS analizi uygulamıştır. Bu analizde 25 adet referans gösterge belirlemek suretiyle gruplara göre karşılaştırmalı analizini gerçekleştirmiştir. Elde edilen sonuçlara göre; kamu sermayeli mevduat bankalarının sermaye yeterliliği, piyasa risklerine duyarlılık ve yönetim yeterliliği açısından; özel sermayeli mevduat bankalarının kârlılık bileşeni yönünden ve yabancı sermayeli mevduat banklarının aktif kalitesi ve likidite bileşeni yönünden diğer banka gruplarına göre daha iyi performansa sahip olduğu belirlenmiştir.

Gümüş ve Nalbantoğlu (2015), çalışmalarında Türk Bankacılık Sektöründe bankaların 2002-2013 yılları arasındaki performansını CAMELS analiz ile belirlemeye çalışmışlardır. Bu analizde kamu sermayeli, özel sermayeli, yabancı sermayeli ve katılım bankaları olmak üzere dört banka grubu karşılaştırmalı olarak değerlendirilmiştir. Analiz bulgularına göre özel sermayeli bankalar performans olarak yönetim kalitesi ve kârlılık bileşenleri itibariyle ilk sırada, kamu bankaları ise ikinci sırada yer almıştır. Yabancı bankalarının kârlılık ve yönetim kalitesi bileşenleri yönünden zayıf bir görünüme sahip olduğu, katılım bankalarının sermayesinin ise diğer banka gruplarına göre çeşitli nedenlerle güçsüz olduğu değerlendirilmiştir.

Wanke, Kalam ve Barros (2016) çalışmalarında Malezya Bankalarının 2009'dan 2013'e kadar potansiyel girdi tasarrufu/çıktı artışının gelişimini değerlendirmek için Dinamik Bolluk Tabanlı Modeli (DSBM) kullanarak Malezya ikili bankacılık sisteminin etkinlik değerlendirmesini yapmışlardır. Malezya İslami ve geleneksel bankalarının göreceli etkinliğini değerlendirmek için iki aşamalı bir yaklaşım uygulanan çalışmada ilk olarak 
CAMEL derecelendirme sistemini daha sonra, ikinci aşamada ise, genelleştirilmiş doğrusal karma modellere (GLMM) uygulanan Monte Carlo Markov Zinciri (MCMC) yöntemini etkin tahmin yeteneğine sahip bankacılık performans değerlendirmesi için bir model geliştirme girişiminin parçası olarak DSBM sonuçlarıyla birleştirmişlerdir. Sonuç olarak, İslami bankalarda geleneksel bankalara kıyasla daha yüksek verimsizlik seviyeleri olduğu tespit edilmiştir. Ayrıca, yabancı bankaların etkinlik düzeylerinin ulusal muadillerine göre daha düşük olması, düzenleyici ve kültürel engeller olduğu şeklinde değerlendirilmiştir.

Öztürk Karaçor vd. (2017) çalışmalarında 2003-2015 yılları arasında Türkiye' de faaliyette bulunan kamusal ve özel sermayeli 12 bankanın performanslarını grupları itibariyle CAMELS modeli ile analiz etmişlerdir. Genel olarak kamusal sermayeli banka grubunun aktif kalitesi bileşeni dışında daha iyi performans gösterdiği tespit edilmiştir.

Emir ve Akyüz (2018) CAMELS analizi uyguladıkları çalışmalarında Türkiye' de faaliyette bulunan mevduat bankalarının performans endekslerini oluşturmak üzere 22 mevduat bankasına ait 2003:Q3-2016:Q2 dönemi verilerini kullanmışlardır. Bankalara hem genel olarak hem de gruplar itibariyle CAMELS analizi gerçekleştirmişlerdir. Sonuç olarak; yabancı sermayeli mevduat bankalarının sermaye yeterliliği, aktif kalitesi ve likidite bileşenlerinde, kamusal sermayeli mevduat bankalarının yönetim kabiliyeti ile kârlılık bileşeninde, özel sermayeli mevduat bankalarının ise piyasa riskine duyarlılık bileşeninde en yüksek performansa sahip olduğu belirlenmiştir.

Uslu (2019) yapmış olduğu çalışmada Türkiye'de kurulmuş bulunan 12 yabancı sermayeli bankanın 2010-2016 yıllarını kapsayan performanslarını uzaktan denetim ve izleme amacıyla geliştirilen CAMELS analizi ile ölçmüştür. Elde edilen sonuçlara göre CAMELS analizi kullanılarak yabancı sermayeli bankalarının performansları belirlenmiş olup, buna göre \% 50'sinde 2010 yılına göre 2016 yılında performans azalışı olduğu, performansı en çok artan ilk üç bankanın ise Deutsche Bank, Citibank ve Turkland Bank olduğu öte yandan Deutsche Bank'ın performans skorunun diğer bankalara göre daha çok kırılgan olduğu tespit edilmiştir.

Eyceyurt Batır (2019) çalışmasında kamusal kaynaklı katılım bankalarının CAMELS analizi ile mevcut katılım bankaları ile karşılaştırmalı olarak performanslarını incelemiştir. Analiz sonucuna göre kamusal kaynaklı katılım bankalarının CAMELS analizi çerçevesinde sermaye yapısı, aktif kalitesi, yönetim performansı, kârlılık, likidite, piyasa riski bileşenlerinde bankacılık sektörüne göre daha yüksek performansının olduğu, ayrıca ortalama CAMELS skoruna göre de Ziraat Katılım ve Vakıf Katılım bankalarının incelenen üç yılda da sektör ortalamasının üzerinde skor elde ettiği tespit edilmiştir.

Uslu vd. (2019) çalışmalarında, kamusal ve özel sermayeli mevduat bankalarının risk analizini yapmak üzere 2010-2017 yıllarını kapsayan performanslarını CAMELS analizi ile incelemişlerdir. Yapılan analiz sonucuna göre CAMELS bileşik değerinin kamusal bankaların \%33'ünde ve özel sermayeli bankaların ise \% 75'inde artığı tespit edilmiştir. Öte yandan kamu bankalarının belirtilen yıl aralığında daha iyi performans gösterdiği ve Akbank ile Ziraat Bankası'nın tüm dönemler itibariyle pozitif ve yüksek CAMELS bileşik değerleri ile iyi bir performansa sahip olduğu sonucuna ulaşılmıştır.

Kaygusuz vd. (2020) çalışmalarında aktif büyüklüklerine göre, ilk 10 bankanın 2008- 2017 yılları arasındaki finansal performanslarını karşılaştırmalı bir şekilde incelemişlerdir. Çalışmada, CAMELS değerlendirme bileşenindeki finansal oranlar kullanılmış olup bu oranlar yardımıyla çok kriterli karar verme tekniklerinden TOPSIS yöntemi ile bankaların finansal performansları analiz edilmiştir. Çalışma iki aşamalı olarak uygulama gerçekleştirilerek sonuç itibariyle bankaların finansal performans sonuçları sıralanmıştır. 2008-2017 Genel Toplam Finansal Performans sıralamasına göre, ilk sırada Denizbank A.Ş. son sırada ise Türkiye Halk Bankası A.Ş. olduğu tespit edilmiştir.

Shaddady ve Moore (2019) çalışmalarında CAMELS analizi ile Veri Zarflama Analizini (VZA) bütünleşik olarak uygulamıştır. CAMELS göstergelerinin, bankaların finansal kırılganlığını değerlendirmek için faydalı olan çok boyutlu risk göstergesi olduğu, VZA ise, her bir karar verme birimi (KVB) için doğrusal programlama kullanarak çok ağırlıklı girdilerin çok ağırlıklı çıktılara karşılaştırmalı oranlarını hesaplayan etkin bir sınır tekniği olduğu değerlendirilerek buna göre, VZA'nın CAMELS'e uygulanması, girdileri en aza indirerek ve çıktıları en üst düzeye çıkararak çoklu girdiler ve çok çıtılar ile ilişkilendirmek suretiyle bunlar arasında etkileşime hizmet edeceği değerlendirilmiştir. Bunun geleneksel risk oranlarına göre belirgin bir avantaj 
sağlayacağı ifade edilmiştir. Veri seti 2000'den 2016'ya kadar 2210 Avrupa bankasını kapsamıştır. Elde edilen temel ampirik sonuçlar ise, sermaye düzenleme endeksi değişkenlerinin istikrar üzerinde olumlu bir etkiye sahip olduğunu ortaya koymaktadır. Sonuçlar, banka istikrarı için sermaye yeterliliğinin önemini yeniden vurgulamaktadır. Ayrıca, faaliyet kısıtlamalarının istikrar üzerindeki olumsuz etkisini göstermekte ve geleneksel olmayan finansal faaliyetlerdeki kısıtlamaların, daha düşük bir çeşitlendirme derecesi nedeniyle banka istikrarını tehlikeye attığını göstermektedir. Diğer düzenleyici ve denetleyici değişkenler de istikrarsızlığın nedenleri olarak ortaya çıkmaktadır. Genel olarak, istikrarı yüksek gruplarda yer alan bankalar, düzenleme ve denetimden kaynaklanan şoklara daha duyarlı olduğu sonucuna ulaşılmıştır.

Akyüz vd. (2020) çalışmalarında katılım bankalarının 2013-2017 yılları arasında CAMELS Analizi ile performanslarını ölçmüşlerdir. Analiz sonucunda, her banka için ayrı ayrı değerlendirme yapıldıktan sonra genel olarak analiz edilen katılım bankalarının CAMELS puanlarının 2015 yılından itibaren düştüğü tespit edilmiştir.

Gaul ve Jones (2021) çalışmalarında 1984'ten 2020'ye kadar olan dönemde CAMELS derecelendirmelerini, bilgi içeriklerini ve belirleyicilerini incelemişlerdir. Bileşik CAMELS risk derecelendirmelerini ve bireysel yönetim bileşeni derecelendirmesi, gelecekteki banka performansı ve bankacılık düzenleyicileri ve denetçileri ile ilgili risk ölçümleri için önemli bir tahmin gücüne sahip olduğunu değerlendirmişlerdir. Elde edilen bulgulara göre bankacılık sektöründe yüksek riskli bileşik CAMELS skorlarının oranı arttığında bunun genel olarak banka kredilerinde önemli bir daralmaya ve ülkedeki işsizlik oranında artışa yol açtığı sonucuna ulaşılmıştır.

\section{Araştırmanın Amacı ve Kapsamı}

Bu çalışmanın amacı ülke ekonomisinin kalkınmasına yönelik yatırımların yapılması ve üretimin arttırılması için kaynak sağlayan finans sektöründe önemli bir yeri olan kalkınma ve yatırım bankalarının finansal performanslarını belirlemektir. Bu araştırma çalışmasında Türkiye'de faaliyet gösteren kamusal sermayeli ve özel sermayeli kalkınma ve yatırım bankalarının 2009-2019 yılları arasında 11 yıllık süreyi içeren CAMELS analizi ile finansal performansları ölçülmüştür. Araştırmaya dâhil örneklem kamu sermayeli ve özel sermayeli kalkınma ve yatırım bankalarının listesi aşağıdaki tabloda verilmektedir.

Tablo 3. Araştırma Örneklemi Banka Bilgileri

\begin{tabular}{|l|l|l|}
\hline Gösterim & Banka Adı & Sermayesi Yönünden Durumu \\
\hline $\mathbf{1}$ & İler Bankası A.Ş. & Kamusal Sermayeli \\
\hline $\mathbf{2}$ & Türk Eximbank & Kamusal Sermayeli \\
\hline $\mathbf{3}$ & Türkiye Kalkınma Bankası A.Ş. & Kamusal Sermayeli \\
\hline $\mathbf{4}$ & Aktif Yatırım Bankası A.Ş. & Özel Sermayeli \\
\hline $\mathbf{5}$ & Diler Yatırım Bankası A.Ş. & Özel Sermayeli \\
\hline $\mathbf{6}$ & GSD Yatırım Bankası A.Ş. & Özel Sermayeli \\
\hline $\mathbf{7}$ & İstanbul Takas ve Saklama Bankası A.Ş. & Özel Sermayeli \\
\hline $\mathbf{8}$ & Nurol Yatırım Bankası A.Ş. & Özel Sermayeli \\
\hline $\mathbf{9}$ & Türkiye Sınai Kalkınma Bankası A.Ş. & Özel Sermayeli \\
\hline
\end{tabular}

Uygulama çalışmasında Türkiye'de mevcut faaliyette bulunan 3 kamusal sermayeli ve 6 özel sermayeli kalkınma ve yatırım bankalarının verileri kullanılmıştır. Analize dahil olan tüm bankaların ilgili finansal oranları Türkiye Bankalar Birliği tarafından hazırlanan Türkiye'de bankacılık sistemi seçilmiş rasyolar 20092019 raporundan elde edilmiştir. 


\section{Araştırmanın Yöntemi ve Modeli}

Uzaktan gözetim sistemleri, bankaların mali raporları kullanılarak değişik metotlar uygulanmak suretiyle analiz edilmesi ve değerlendirmesine dayanmaktadır. Uzaktan gözetim sistemlerinde iki yaklaşım bulunmaktadır. Bu yaklaşımlar gözetim ekranları ve ekonometrik modeller şeklinde belirlenebilir. Gözetim ekranları yönteminde, denetçilerce belirlenen ölçütlere göre finansal tablolardan elde edilen verilere dayalı olarak bankaların finansal durumları tespit edilmektedir. Ekonometrik modellerde ise, bankaların finansal durumları ekonometrik yöntemlerden yararlanarak belirlenmektedir. Uygulanma yöntemleri yönünden farklı özelliklere sahip olan yerinde denetim ve uzaktan gözetim sistemleri, denetim ve gözetim yetkililerine farklı alanlarda avantaj sağlayabilmektedir. Bu nedenle etkin denetim ve gözetim gerçekleştirmek üzere denetim ve gözetim yetkilileri bu iki sistemi de aynı anda kullanabilmektedirler. Bankaların denetimi ile ilgili olarak yaygın olarak bilinen adıyla CAMELS dereceleme sistemi buna iyi bir örnek teşkil etmektedir (Arıçelik, 2010:77-78)

CAMELS değerlendirme sistemi ABD'de geliştirilmiş olup; bankaların performansının ve genel durumunun belirlenmesinde ve uzaktan gözetim faaliyetlerinde kullanılmaktadır. CAMELS sistemi ilk olarak ortaya çıktığında 5 bileşenden oluşmakta iken 1997 yılından sonra piyasa risklerine karşı duyarlılı̆̆ın da sisteme eklenmesiyle birlikte sistem 6 bileşeni bünyesinde barındırmaya başlamıştır. Söz konusu bileşenler; (Öztürk Karaçor vd., 2017:50-51)

- Sermaye yeterliliğgi (C), aniden oluşan gelişmeler durumunda bankalara güvence oluşturmaktadır. Bu yönde banka sermayesi mevduat sahipleri için güvence sağlaması, zorunlu sabit sermaye yatırımlarını karşılaması ve risk durumlarında banka faaliyetlerinin sürekliliğinin sağlanmasında önemli görülmektedir.

- $\quad$ Aktif kalitesi (A) bu bileşenin temel unsurlarından birisi kredilerin kalitesi olarak görülmektedir. Bu durumda en önemli risk unsuru, geri ödenmeyen kredilerde artış bulunmasıdır.

- Yönetim yeterliliği (M); yönetimin yeteneğini ve kabiliyetini göstermektedir. Bu bileşenle risklerin belirlenmesi hususunda yeterlilik durumu sorgulanmaktadır.

- Kazanç durumu (E); bankaların faaliyetlerini düzenli bir biçimde yerine getirebilmesi için ön şartlardan birisidir. Bu bileşen bankaların kârlılık durumlarını değerlendirmektedir.

- Likidite durumu (L); bankaların kısa vadeli borçlarını ve beklenmedik nakit çıkışlarını karşılayabilme kapasitesini göstermektedir. Bankaların fon yönetimi, likidite seviyesinde en önemli belirleyicidir.

- Piyasa riskine karşı duyarlılık (S); bankaların önemli seviyede etkileyebilme ihtimali bulunan faiz oranları, döviz kurları, mal ve hisse senedi fiyatları gibi ekonomik faktörlerin incelendiği bileşendir.

CAMELS analizi sonuçlarının derecelendirilmesi 1-5 arası skorlarla belirlenmektedir. Buna göre 1 skoru en iyi performans derecesini ve 5 skoru en kötü performans derecesini göstermektedir. Değerlendirmede kullanılacak bileşen ağırlı̆̆ı, bileşeni oluşturan finansal oranların ağırlığı belirlenen amaç yönünden belli özelliklere göre araştırmayı yapan tarafından oluşturulmaktadır. CAMELS bileşenleri sonucu elde edilen sonuçların değerlendirilmesi neticesinde puanların anlamları ise şöyle sıralanabilir. "1" puanı her açıdan güçlü olduğu anlamına gelmektedir. Burada her bileşen için elde edilen not 1 ya da 2 olması gerekmektedir. "2" puanı genel olarak güçlü anlamına gelmektedir. Bankanın bütün bileşen değeri 3'ten kötü olmaması gerekmektedir. "3" puanı bankanın etkinliği ile ilgili sorunların bulunduğunu göstermektedir. Muhtemel şoklarda yeterli seviyede dayanıklı olmadığını göstermektedir. " 4 " puanı genel olarak ciddi problemlerin bulunduğunu göstermektedir. Finansal ve yönetimsel sorunların yaşandığını göstermekte olup, banka performansı kötü olarak değerlendirilmektedir. " 5 " puanı ise, çok ciddi finansal veya yönetimsel sorunların olduğunu ve bankanın batma riskinin yüksek olduğunu göstermektedir (Uslu, 2019:205).

CAMELS analizi ile tespit edilen zayıflık gerekli tedbirlerin alınması için yönetime ve yönetim kurullarına raporlanması gerekmektedir. CAMELS dereceleri özel durum içerdiği dolayısıyla kamuoyuyla paylaşılmaması icap etmektedir. Çünkü bu analiz neticesinde elde edilen bilgiler nedeniyle mevduatların geri çekilmesi ve dolayısıyla bankanın finansal sıkıntıya girmesi ve hatta kamuoyunun bütün bankacılık sistemine olan güveninin zedelenmesine sebep olabilir (Kandemir ve Arıcı, 2013:66)

CAMELS uygulama çalışmasında Türkiye bankacılık sektöründe faaliyet gösteren kamusal ve özel sermayeli mevduat bankalarının 2009-2019 dönemine ilişkin finansal verileri değerlendirilmiştir. Kullanılan finansal oranlar, Türkiye Bankalar Birliğinin düzenli olarak yayınladığı "Seçilmiş Rasyolar" istatistiklerinden elde 


\section{E. Özgür 13/4 (2021) 3206-3221}

edilmiştir. Analiz uygulama dönemi olan 2009-2019 yılları arasında aktif olmadıkları veya ilgili finansal oranları yönünden aşırı bir miktar gösterdiği belirlenen mevduat bankaları yapılan analizde doğru neticenin alınmasında katkı sağlamayacağı düşünüldüğü dolayısıyla kapsama alınmamıştır. Çalışma 11 mevduat bankası ile gerçekleştirilmiştir. Bu bankalardan 3'ü kamusal sermayeli ve 9'u ise özel sermayeli bankasıdır. İlgili bankaların 2009-2019 dönemine ilişkin 21 finansal oranı ile CAMELS analizi çalışması yapılmıştır. Uygulama çalışmasında bileşenlerden; Sermaye Yeterliliği \%20, Aktif Kalitesi \%20, Yönetim Kalitesi \%20, Kârlılık \%20, Likidite \%10 ve Piyasa Risklerine Duyarlılık \%10 ağırlıklı olarak değerlendirilerek CAMELS analizi gerçekleştirilmiştir.

Araştırma çalışmasının modeli ile ilgili olarak mevduat bankalarının; Sermaye Yeterliliği ( C ), Aktif Kalitesi ( A ), Yönetim Kalitesi ( M ), Karlılık ( E ), Likidite ( L ), Piyasa Risklerine Duyarlılık ( S ) harfleri ile ifade edilmektedir. Literatürde başka araştırmalarda da kullanılmış finansal oranlar dikkate alınarak belirtilen konularda veri setleri oluşturulmuştur. Çalışmanın analiz uygulamasında kullanılan değişkenler ve etki oranları Tablo 4.'te gösterilmektedir.

Tablo 4. Analizde Kullanılan Finansal Oranlar ve Ağırlıkları

\begin{tabular}{|c|c|c|c|c|}
\hline AÇIKLAMASI & SIMGE & ETKİ YÖNÜ & $\begin{array}{l}\text { AĞIRLIĞI } \\
(\%)\end{array}$ & KATSAYISI \\
\hline SERMAYE YETERLİLİĞİ (C) & & & & 0,2 \\
\hline Sermaye Yeterlilik Oranı & $\mathrm{C} 1$ & Pozitif & 30 & 0,3 \\
\hline Öz Kaynaklar / Toplam Aktifler & $\mathrm{C} 2$ & Pozitif & 30 & 0,3 \\
\hline (Özkaynaklar-Duran Aktifler) / Toplam Aktifler & $\mathrm{C} 3$ & Pozitif & 20 & 0,2 \\
\hline Özkaynaklar / (Mevduat + Mevduat Dışı Kaynaklar) & C5 & Pozitif & 20 & 0,2 \\
\hline AKTíF KALİTESİ (A) & & & & 0,2 \\
\hline Toplam Krediler / Toplam Varlıklar & A1 & Pozitif & 30 & 0,4 \\
\hline Duran Varlıklar / Toplam Varlıklar & $\mathrm{A} 3$ & Negatif & 20 & 0,2 \\
\hline Finansal Varlıklar (Net) / Toplam Varlıklar & $\mathrm{A} 4$ & Negatif & 30 & 0,4 \\
\hline YÖNETIM KALİTESİ (M) & & & & 0,2 \\
\hline Faiz Giderleri / Toplam Giderler & M1 & Negatif & 25 & 0,25 \\
\hline Faiz Gelirleri / Toplam Gelirler & M2 & Pozitif & 25 & 0,25 \\
\hline $\begin{array}{l}\text { Özel Karşlıklar Sonrası Net Faiz Geliri / Toplam } \\
\text { Varlıklar }\end{array}$ & M3 & Pozitif & 25 & 0,25 \\
\hline Faiz Dışı Gelirler (Net) / Toplam Varlıklar & M4 & Pozitif & 25 & 0,25 \\
\hline KÂRLILIK (E) & & & & 0,2 \\
\hline Ortalama Aktif Karlılığı & E1 & Pozitif & 25 & 0,25 \\
\hline Ortalama Özkaynak Karlılığı & E2 & Pozitif & 25 & 0,25 \\
\hline Vergi Öncesi Kâr / Toplam Aktifler & E3 & Pozitif & 25 & 0,25 \\
\hline Net Dönem Kârı (Zararı) / Ödenmiş Sermaye & E4 & Pozitif & 25 & 0,25 \\
\hline LİKİDİTE (L) & & & & 0,1 \\
\hline Likit Aktifler / Toplam Aktifler & L1 & Pozitif & 40 & 0,4 \\
\hline Likit Aktifler / Kısa Vadeli Yükümlülükler & L2 & Pozitif & 30 & 0,3 \\
\hline Likit Aktifler / (Mevduat + Mevduat Dışı Kaynaklar) & L3 & Pozitif & 30 & 0,3 \\
\hline PİYASA RİSKİNE DUYARLILIK (S) & & & & 0,1 \\
\hline YP Yükümlülükler / Toplam Yükümlülükler & S1 & Negatif & 30 & 0,3 \\
\hline Net Bilanço Pozisyonu / Özkaynaklar & S3 & Negatif & 40 & 0,4 \\
\hline Donuk Alacaklar / Toplam Krediler & S4 & Negatif & 30 & 0,3 \\
\hline
\end{tabular}

Bankaların performanslarının belirlenmesi ve CAMELS skorunun bulunması belirli hesaplama aşamaları ile oluşmaktadır. Bu konuda referans değeri, endeks değeri, sapma değeri, genel faktör ağırlıklı değeri, CAMELS gösterge değeri hesaplanarak nihayet CAMELS skoru bulunmaktadır. CAMELS skorunun hesaplanması hususunda ayrıntılı açıklamalar ve aşamaları Tablo 5 'te gösterilmektedir. 
E. Özgür 13/4 (2021) 3206-3221

Tablo 5. CAMELS Analizi Uygulama Aşamaları

\begin{tabular}{|c|c|c|}
\hline Açıklama & Aşaması & Uygulama yönergesi \\
\hline $\begin{array}{l}\text { Genel faktörün bileşenleri finansal } \\
\text { oranların saptanması }\end{array}$ & A & $\begin{array}{l}\text { Literatürde uygulama durumu da değerlendirilerek } \\
\text { genel faktör ile ilgili finansal oranlar belirlenir }\end{array}$ \\
\hline Etki yönünün belirlenmesi & B & $\begin{array}{l}\text { Finansal oranda meydana gelen değişimin genel } \\
\text { faktör üzerinde pozitif veya negatif etkisinin } \\
\text { saptanması }\end{array}$ \\
\hline $\begin{array}{l}\text { Genel faktörün } \text { ağırlığının } \\
\text { belirlenmesi }\end{array}$ & $\mathrm{C}$ & $\begin{array}{l}\text { Toplam analiz çerçevesinde genel faktörün } \\
\text { ağırlığının belirlenmesi }\end{array}$ \\
\hline Finansal Orana Verilen Ağırlık (\%) & $\mathrm{D}$ & $\begin{array}{l}\text { Finansal oranın ilgili faktör içindeki eti oranının } \\
\text { belirlenmesi }\end{array}$ \\
\hline Referans Değeri & E & $\begin{array}{l}\text { Hesaplanan döneme ilişkin uygulama örneklemi } \\
\text { bankaların ilgili finansal oranlarının aritmetik } \\
\text { ortalaması }\end{array}$ \\
\hline Endeks Değeri & G & $\begin{array}{l}\text { Finansal oranın referans değere bölünmesi ve } 100 \text { ile } \\
\text { çarpılması sonucu elde edilen değer }\end{array}$ \\
\hline Sapma Değeri & $\mathrm{H}$ & $\begin{array}{l}\text { İlişki yönü pozitif ise endeks değer-100 } \\
\text { İlişki yönü negatif ise; 100- endeks değer şeklinde } \\
\text { bulunan değer }\end{array}$ \\
\hline Ăğırlıklı Değerler & I & $\begin{array}{l}\text { Finansal oranın etki oranı ile sapma değerin } \\
\text { çarpılması sonucu bulunan değer }\end{array}$ \\
\hline Genel Faktör Ağırlık Değeri & $\mathrm{J}$ & $\begin{array}{l}\text { Her bir finansal oran için elde edilen ağırlıklı } \\
\text { değerin toplanarak genel faktör etki oranı ile } \\
\text { çarpılması sonucu ortaya çıkan değer }\end{array}$ \\
\hline CAMEL Gösterge Değeri & K & $\begin{array}{l}\text { Her bir genel faktör ağırlıklı değerinin toplamının } \\
\text { alınması sonucu ortaya çıkan değer }\end{array}$ \\
\hline CAMELS Skoru & $\mathrm{L}$ & $\begin{array}{l}\text { Her bir banka için bulunan CAMELS gösterge } \\
\text { değerinin 1-5 arasında puanlanarak ilgili bankanın } \\
\text { kapsamdaki diğer bankalara göre performans skoru } \\
\text { belirlenmesi }\end{array}$ \\
\hline
\end{tabular}

Kaynak: Arıçelik, 2010:90; Kandemir ve Arıcı, 2013:73; Akyüz vd. 2020:153

\section{Araştırmanın Bulguları}

Çalışmada kamusal sermayeli ve özel sermayeli kalkınma ve yatırım bankalarının performanslarının ölçümü için CAMELS analizi uygulanmıştır. Yapılan analizde Tablo 3.'te belirtilen bankalarla ilgili olarak Tablo 4'te belirtilen finansal oranlar ve ağırlıkları kullanılarak Tablo 5 'teki uygulama aşamaları ile modelin hesaplaması yapılmaktadır. Uygulama çalışmasında literatürde bankacılık sektörü ile ilgili olarak başka çalışmalarda kullanılan oranlar ve bu değişkenlerle bileşen faktörlere uygulanan ağırlık katsayıları dikkate alınarak bu çalışmaya özgü bir veri seti ile ağırlık katsayısı belirlenmiş ve özgün bir analiz gerçekleştirilmiştir. Bankaların 2009-2019 yılları itibariyle 11 yıllık süreci kapsayan analize dahil tüm bankaların CAMELS gösterge değeri hesaplanmıştır. Uygulama çalışmasındaki bankalar için ayrı ayrı analiz sonucu yıllar itibariyle CAMELS gösterge değeri gelişim eğilimi aşağıda gösterilmektedir. 


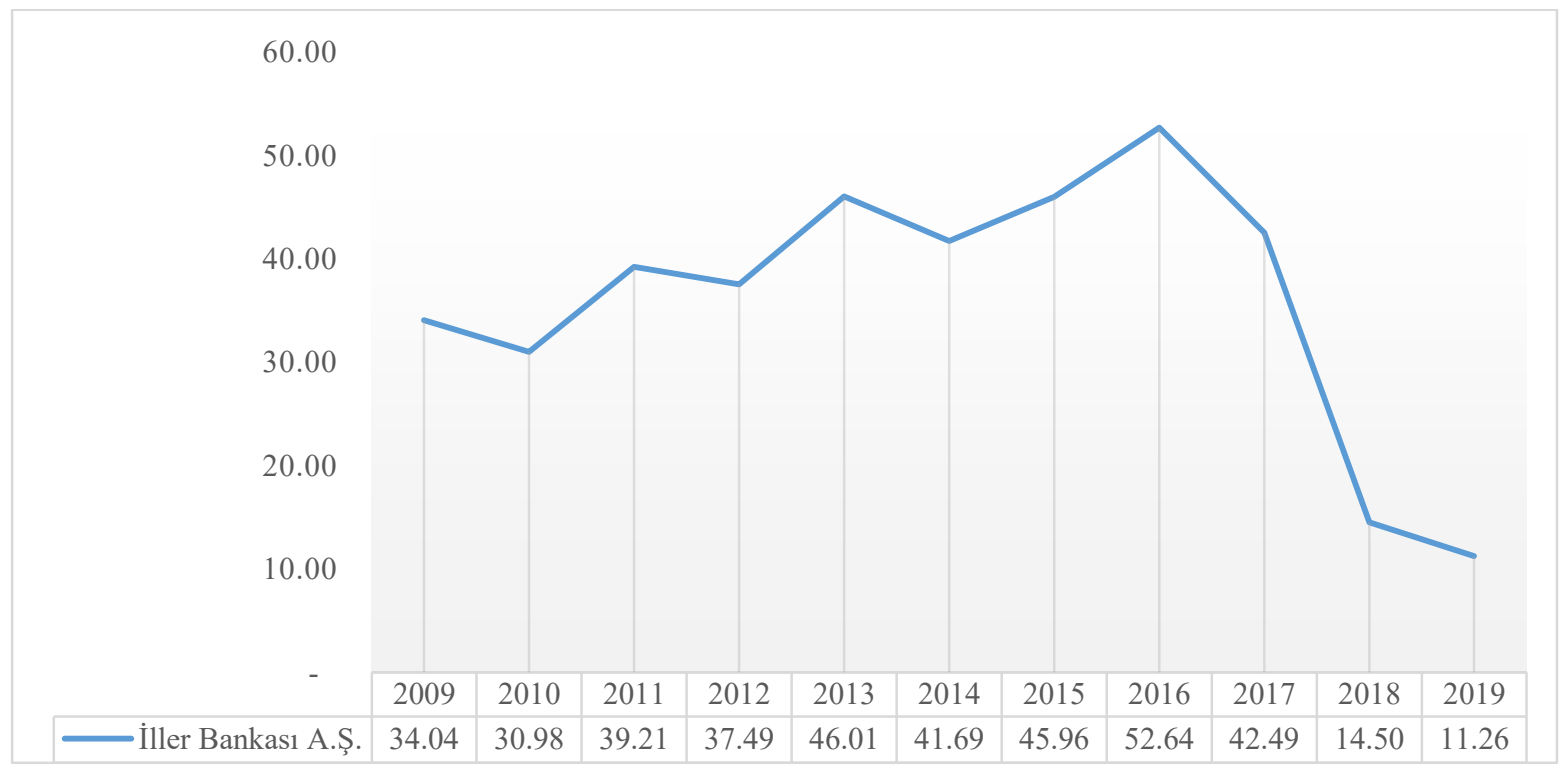

Şekil 1. İller Bankası A.Ş. CAMELS Analizi Sonucu (2009-2019)

Kamusal sermayeli İller Bankası A.Ş.'nin CAMELS Göster Değeri 2010 yılından itibaren 2016 yılına kadar artış göstermiş olup, 2016 yllından sonra ise düşüş yönünde hareket etmekle birlikte 2019 yılı itibariyle 11,26 seviyesinde pozitif değerde görülmektedir. 2009-2019 yılları arasında 11 yıllık süreçte tüm yıllar pozitif değer almıştır.

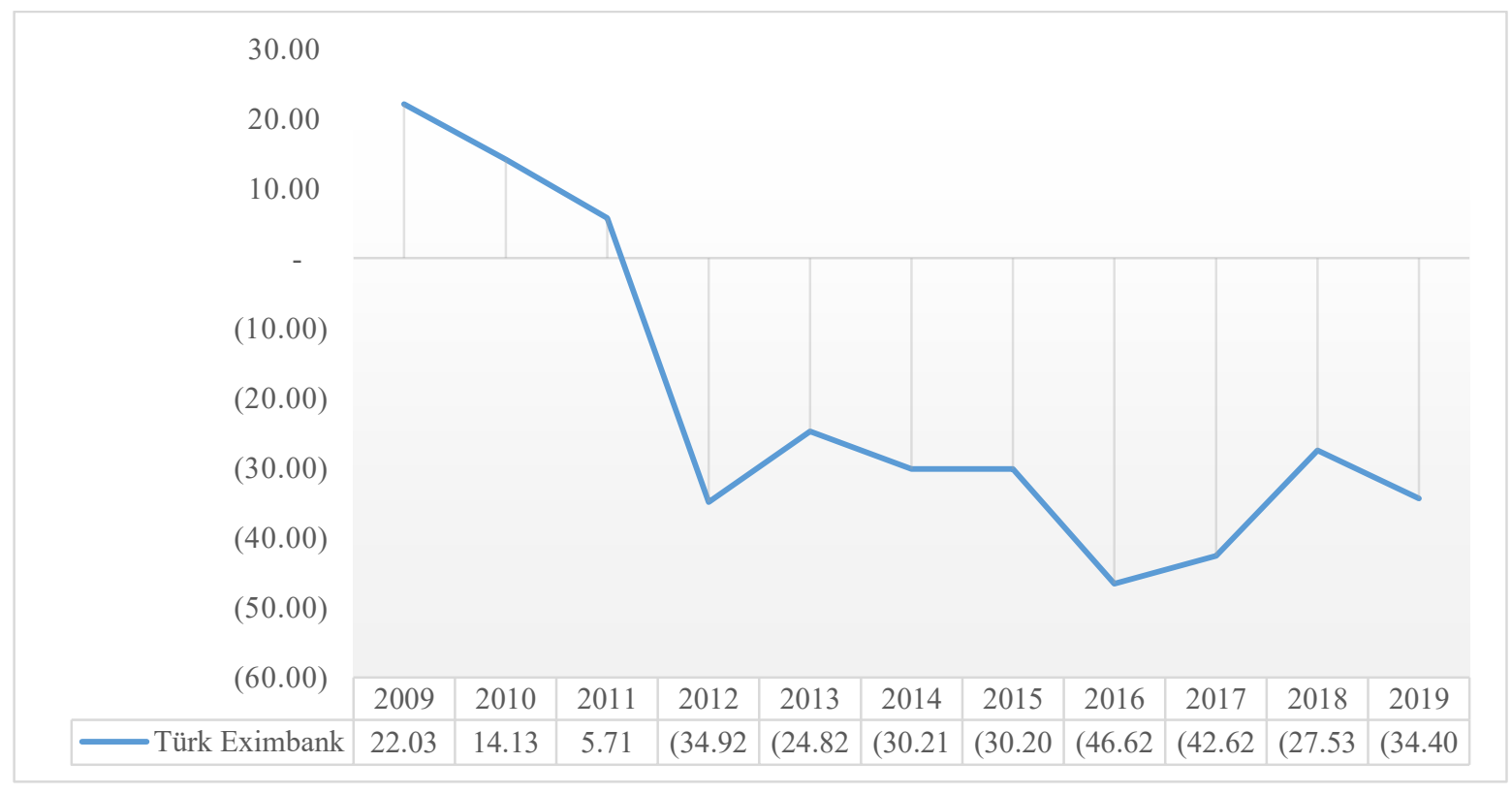

Şekil 2. Türk Eximbank CAMELS Analizi Sonucu (2009-2019)

Kamusal sermayeli Türk Eximbank CAMELS Gösterge Değeri 2009 yılında 22,03 değerinde iken yıllar itibariyle düşüş kaydederek 2016 yılında -46,62 seviyesine inmiş olup, sonraki yıllarda yükselişe geçerek 2019 yılı itibariyle -34,40 şeklindedir. 2009-2019 yılları arasında 2009-2010-2011 yılları pozitif değer alırken diğer 8 yıl negatif değer almıştır. 


\subsection{0}

$(10.00)$

$(20.00)$

$(30.00)$

$(40.00)$

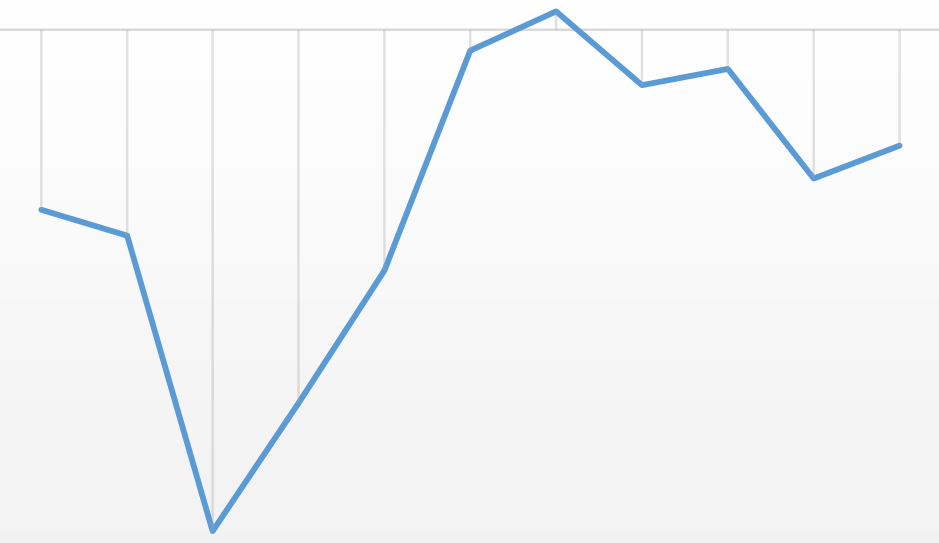

$(50.00)$

\begin{tabular}{|l|l|l|l|l|l|l|l|l|l|l|}
2009 & 2010 & 2011 & 2012 & 2013 & 2014 & 2015 & 2016 & 2017 & 2018 & 2019 \\
\hline
\end{tabular}

-Türkiye Kalkınma Bankası A.Ş. (16.15(18.44(44.95(33.47(21.61)(1.88) 1.63 (4.97) (3.53) (13.34(10.40

Şekil 3. Türkiye Kalkınma Bankası A.Ş. CAMELS Analizi Sonucu (2009-2019)

Kamusal sermayeli Türkiye Kalkınma Bankası A.Ş. CAMELS Gösterge Değeri sürekli olarak negatif bölgede olmakla birlikte en dip seviyeye -44,95 değeri 2011 yılında almış olup, sonraki yıllarda artış eğilimi göstererek 2019 yılı itibariyle -10,40 seviyesindedir. 2009-2019 yılları arasında sadece 2015 yılında pozitif değer almıştır.

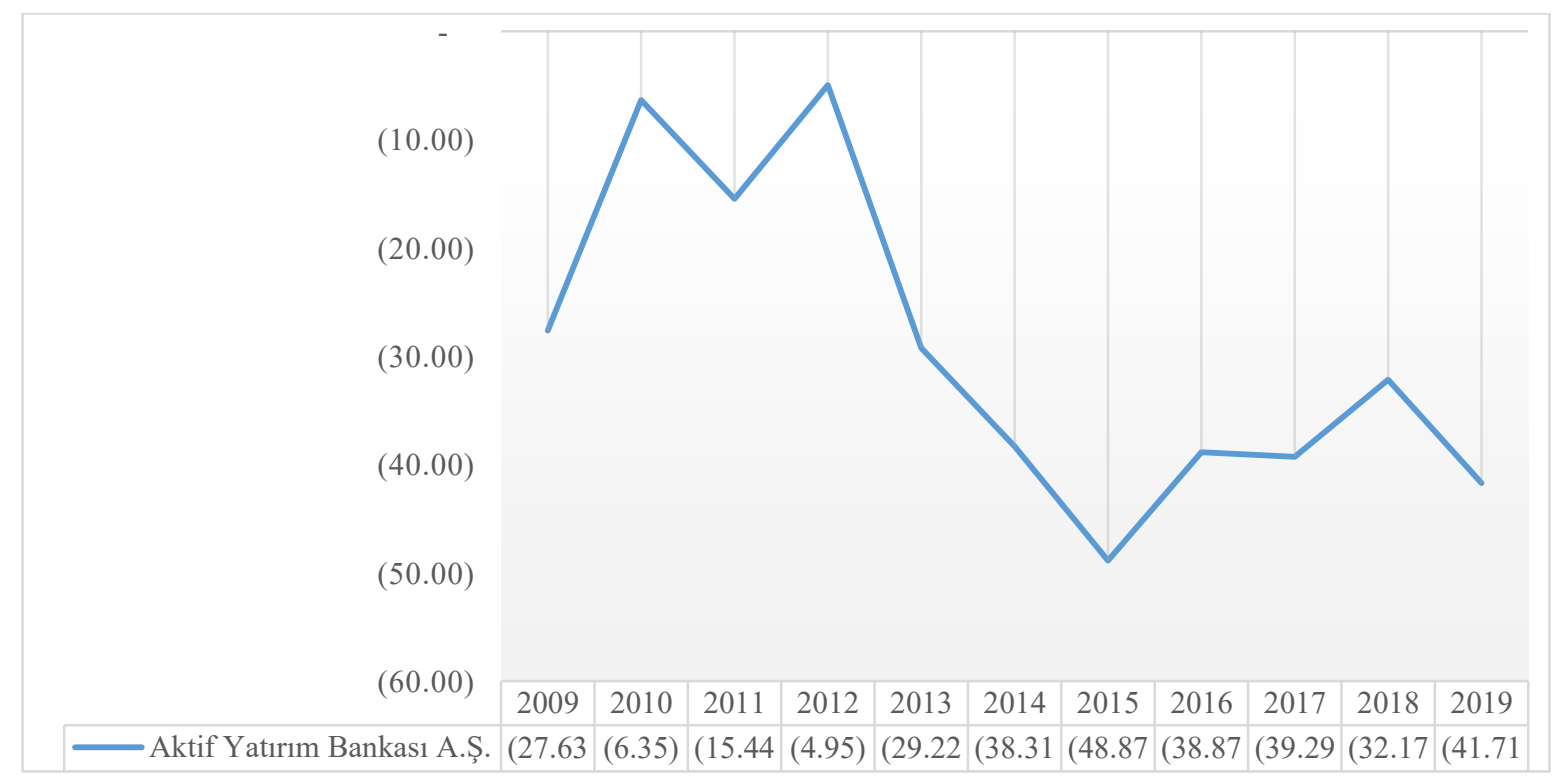

Şekil 4. Aktif Yatırım Bankası A.Ş. CAMELS Analizi Sonucu (2009-2019)

Aktif Yatırım Bankası A.Ş. CAMELS Gösterge Değeri analiz yapılan 2009-2019 döneminde tüm yıllar negatif bölgede bulunmaktadır. 2009 yılından sonra artış kaydeden gösterge değeri 2012 yılından sonra düşmeye başlamış olup, en dip seviyeyi 2015 yılında -48,87 değeri ile görmüştür. 


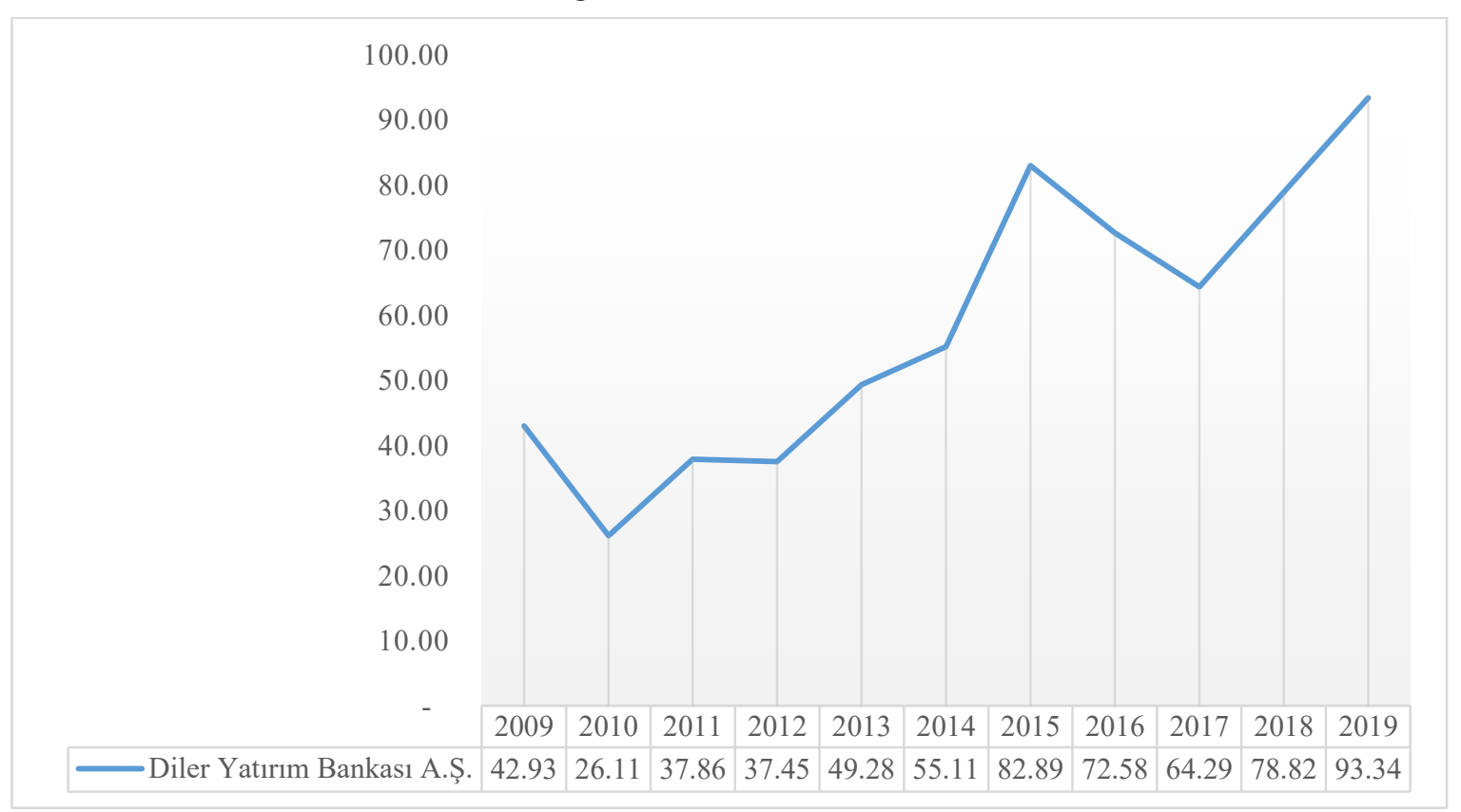

Şekil 5. Diler Yatırım Bankası A.Ş. CAMELS Analizi Sonucu (2009-2019)

Diler Yatırım Bankası A.Ş. CAMELS Gösterge Değeri analiz yapılan 2009-2019 döneminde tüm yıllarda pozitif bölgede olup, 2010 yılında 26,11 olan gösterge değeri yıllar itibariyle artarak 2019 yılında 93,34 olarak tespit edilmektedir.

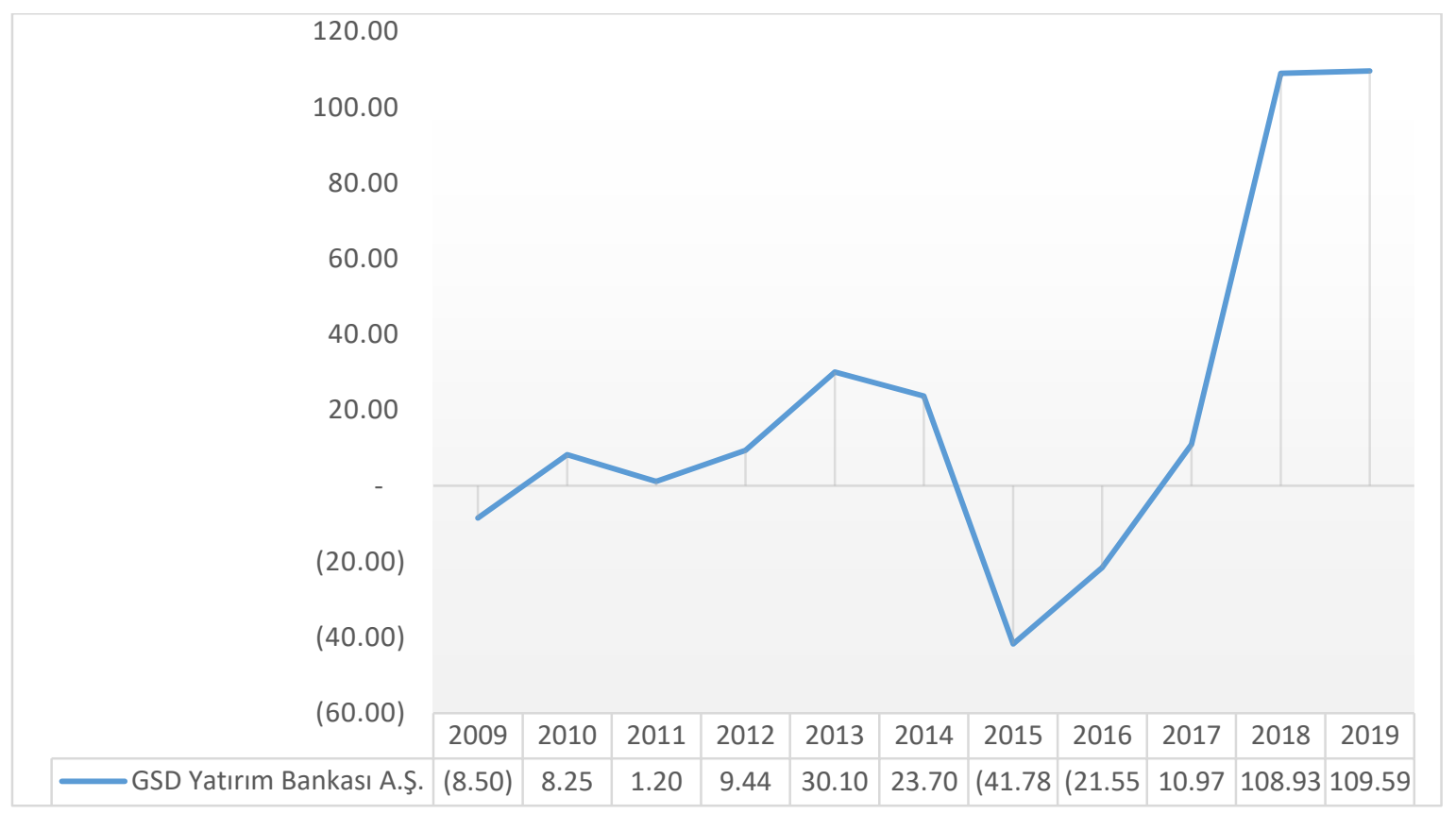

Şekil 6. GSD Yatırım Bankası A.Ş. CAMELS Analizi Sonucu (2009-2019)

GSD Yatırım Bankası A.Ş. CAMELS Gösterge Değeri genel olarak pozitif bölgede olmakla birlikte 2015 yılında $-41,78$ seviyesini görmüş olup, daha sonraki yıllarda artarak 2019 yılı itibariyle 109,5 değeri almıştır. Analiz yapılan dönem kapsamında 2009-2015-2016 yıllarında negatif değer almış olup, diğer 8 yıl pozitif değer almıştır. 


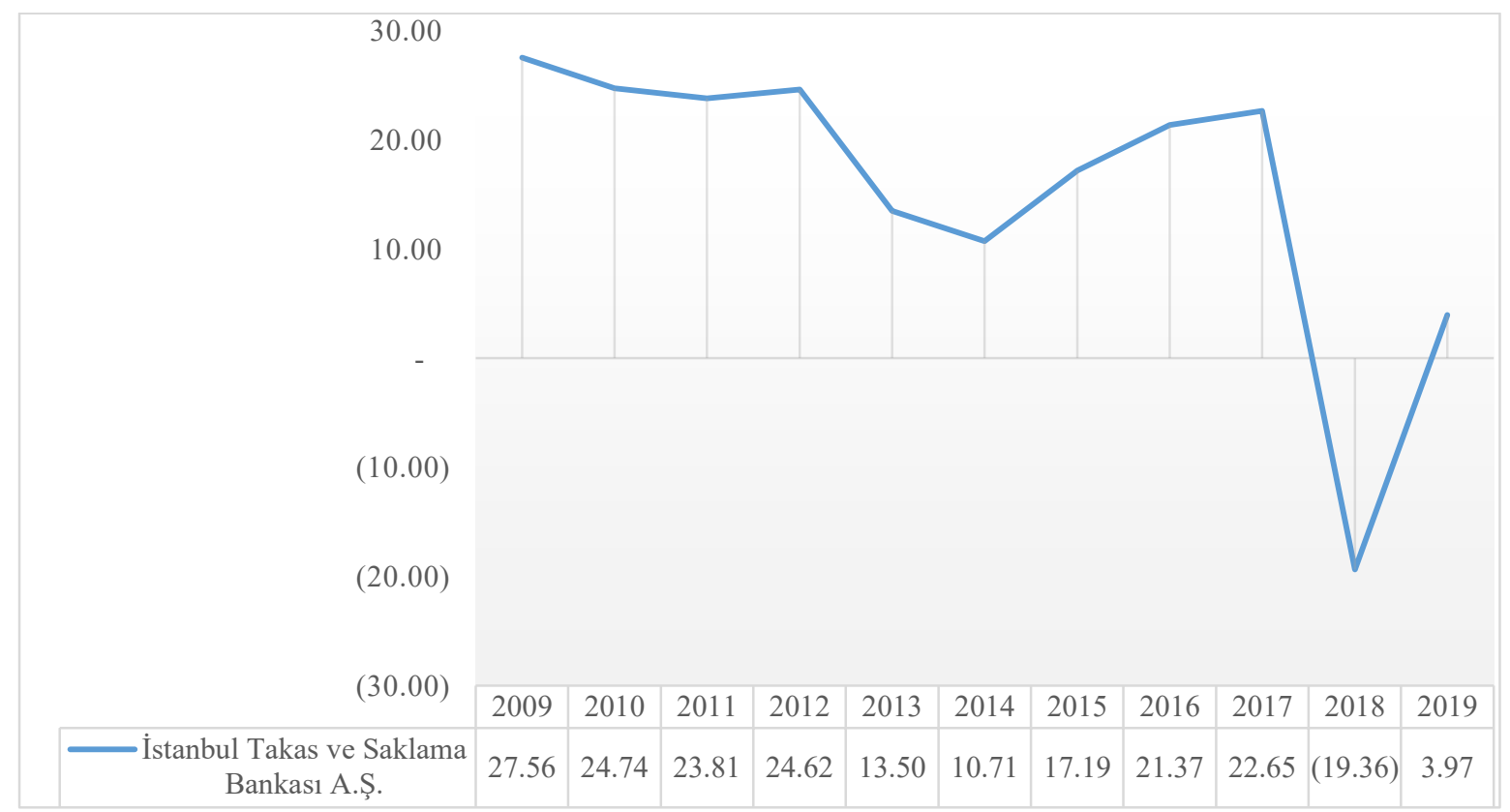

Şekil 7. İstanbul Takas ve Saklama Bankası A.Ş. CAMELS Analizi Sonucu (2009-2019)

İstanbul Takas ve Saklama Bankası A.Ş. CAMELS Gösterge Değeri 2009 yılından 2017 yılına kadar pozitif ve yatay olarak değer alırken, 2018 yılında -19,36 değer ile 1 yıl negatif bölgede görülmektedir. 2019 yılında ise 3,97 değer almıştır. Böylece 2009-2019 yılları arasında 10 yıl pozitif ve 1 yıl negatif değer almıştır.

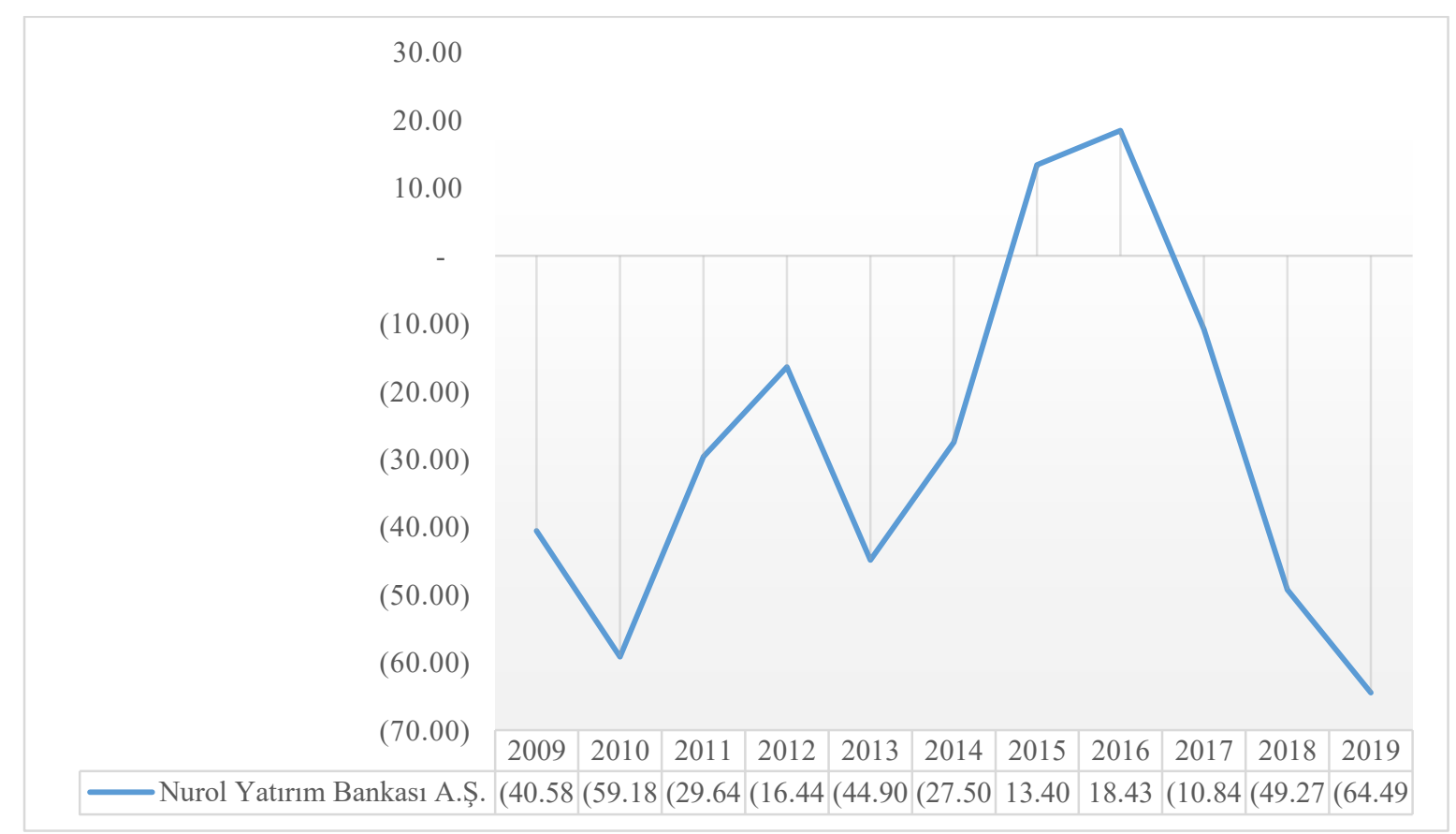

Şekil 8. Nurol Yatırım Bankası A.Ş. CAMELS Analizi Sonucu (2009-2019)

Nurol Yatırım Bankası A.Ş. CAMELS Gösterge Değeri genel olarak negatif bölgede ancak yükseliş eğilimi sürdürerek 2015 yılında 13,40 ve 2016 yılında 18,43 değer aldıktan sonra tekrar düşüş eğilimine girmiş ve 2019 yılında -69,49 değer almıştır. 2009-2019 yılları arasında 9 yıl negatif ve 2 yıl pozitif değer almıştır. 


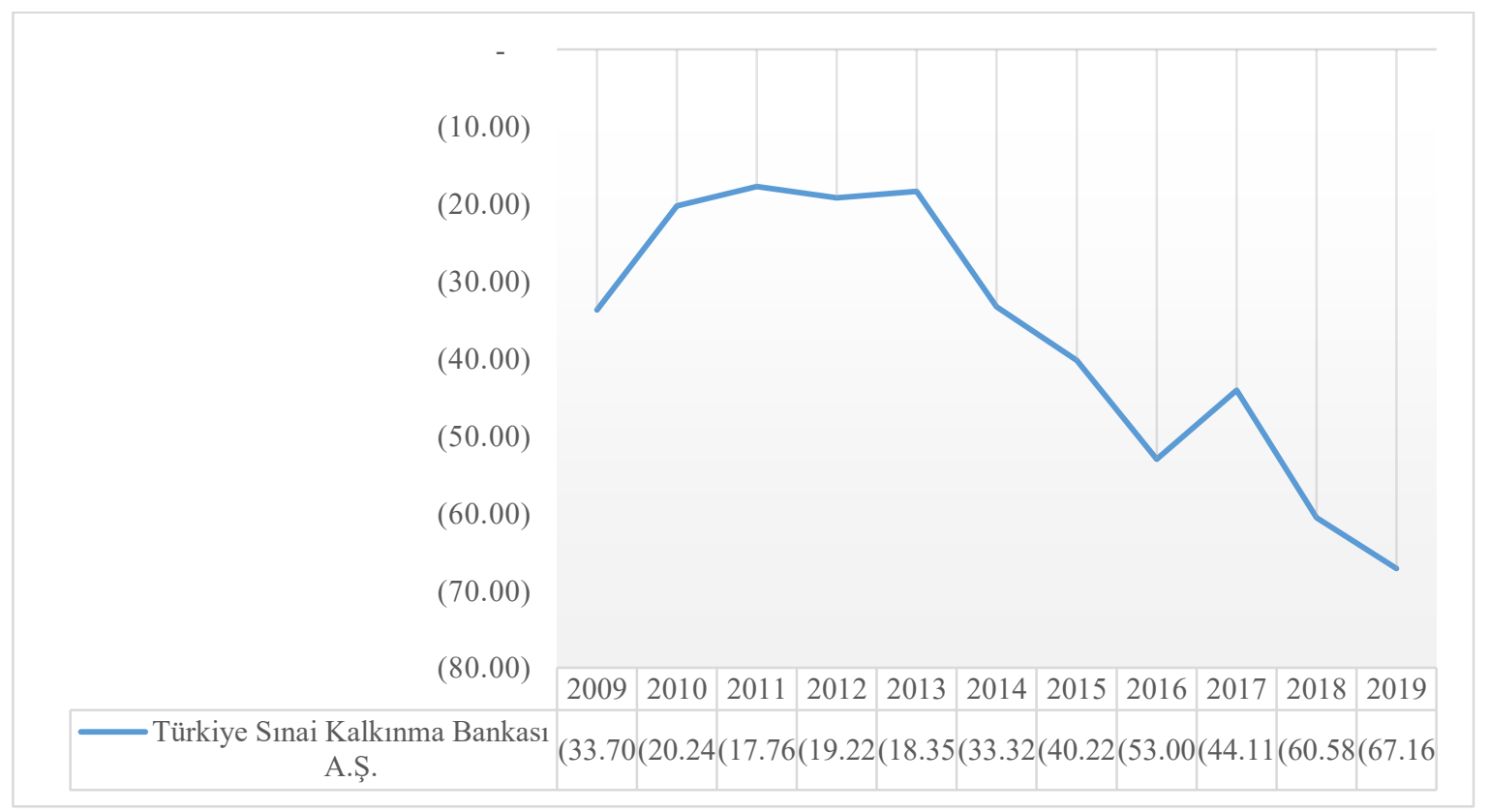

Şekil 9. Türkiye Sınai Kalkınma Bankası A.Ş. CAMELS Analizi Sonucu (2009-2019)

Türkiye Sınai Kalkınma Bankası A.Ş. CAMELS Gösterge Değeri 2009-2019 yılları arasında tüm yıllar negatif değer almış olup, 2011 yılında -17,76 iken yıllar itibariyle düşüş eğilimi göstererek 2019 yılında -67,16 seviyesinde görülmektedir.

Araştırma çalışmasında elde edilen bulgular birlikte değerlendirildiğinde; Türkiye'de faaliyet gösteren kamusal sermayeli ve özel sermayeli kalkınma ve yatırım bankalarının CAMELS derecelendirme sistemi ile 2009-2019 yılları arasında gelişim sürecinde aldıkları gösterge değerleri pozitif ve negatif yıllar itibariyle her bir banka için aşağıdaki gibidir.

- $\quad$ İller Bankası A.Ş. ve Diler Yatırım Bankası A.Ş. CAMELS Göster Değeri 2009-2019 yılları arasında 11 yıllık süreçte tüm yıllar pozitif değer almıştır.

- İstanbul Takas ve Saklama Bankası A.Ş. CAMELS Göster Değeri 2009-2019 yılları arasında 10 yıl pozitif ve 1 yıl negatif değer almıştır.

- GSD Yatırım Bankası A.Ş. CAMELS Göster Değeri 2009-2019 yılları arasında 2009-2015-2016 yıllarında negatif değer almış olup kalan 8 yıl pozitif değerdedir.

- Türk Eximbank CAMELS Göster Değeri 2009-2019 yılları arasında 2009-2010-2011 yılları pozitif değer alırken diğer 8 yıl negatif değerdedir.

- Nurol Yatırım Bankası A.Ş. CAMELS Göster Değeri 2009-2019 yılları arasında 9 yıl negatif 2 yıl pozitif değer almiştır.

- Türkiye Kalkınma Bankası A.Ş. CAMELS Göster Değeri 2009-2019 yılları arasında sadece 2015 yılında pozitif değer almış diğer $10 \mathrm{y}$ ll ise negatif değerdedir.

- $\quad$ Aktif Yatırım Bankası A.Ş. ve Türkiye Sınai Kalkınma Bankası A.Ş. CAMELS Göster Değeri analiz yapılan 2009-2019 döneminde tüm yıllar negatif değer almıştır.

Kalkınma ve yatırım bankaları ile ilgili olarak Şenel ve Şekercioğlu (2019) tarafından yapılan çalışmada Türkiye'de faaliyet gösteren kalkınma ve yatırım bankalarının 2013-2017 yılları arasında gösterdiği performans Veri Zarflama Analizi kullanılarak etkinlik değerleri hesaplanmıştır. Bu çalışma ile benzer şekilde bulgulara ulaşılan araştırmada İller Bankası A.Ş. ve Diler Yatırım Bankası A.Ş. analiz yapılan tüm yıllarda etkin olduğu, Türkiye Kalkınma Bankası A.Ş. tüm yıllarda, Aktif Yatırım Bankası A.Ş. ise 2013-2015 yılları arasında etkinlik sınırının altında olduğu tespit edilmiştir. Araştırma çalışmasında farklı bir ekonometrik analiz yöntemi kullanılmakla birlikte, elde edilen bulgular yönünden bu çalışmayı teyit eder niteliktedir. 


\section{Sonuç}

2009-2019 yılları arasında faaliyette bulunan 3'ü kamusal sermayeli, 6'sı özel sermayeli olmak üzere toplamda 9 kalkınma ve yatırım bankası ile analiz gerçekleştirilmiştir. İlgili bankaların 2009-2019 dönemine ait bilanço ve gelir tabloları kullanılarak elde edilen 6 bileşen kapsamında 21 mali oran kullanılmıştır.

Elde edilen veriler ışığında, CAMELS gösterge değerleri yönünden kalkınma ve yatırım bankalarının bazıları tüm yıllar pozitif değer alarak finansal verileri itibariyle derecesi diğer bankalardan daha yüksek olup, başka bazı kalkınma ve yatırım bankaları tüm yıllar negatif değer aldıkları ve diğer bankaların ise belirli yıllar pozitif belirli yıllar negatif değer aldıkları belirlenmiştir. Negatif değer alan kalkınma ve yatırım bankaların finansal bazı oranlarının kontrol edilmesi ve tedbir alınması gerektiği düşünülmüştür.

$\mathrm{Bu}$ analiz geçmiş duruma ilişkin bir bilgi vermekle birlikte bu bilgilerden yola çıkarak banka yöneticilerinin finansal tabloları itibariyle alacakları kararlar ve uygulamaların hangi kalemde nasıl etkide bulunmakta olduğu ve netice itibariyle CAMELS gösterge değerini nasıl etkilediği hususunda değerlendirme yapma imkânları bulunmaktadır. Alınan sonuçlar banka yetkililerine hem yol göstermekte hem de gelecek yönelimli perspektiflerinde ne tür bir tutum ve davranış içinde olmaları gerektiği hususunda belirli ipuçları vermektedir.

Yapılan bu çalışma, kalkınma ve yatırım bankaları ile ilgili CAMELS analizi içeren özgün bir yapıya sahiptir. CAMELS derecelendirme yöntemi kullanılmak suretiyle bileşenlerde farklı finansal oranlar kullanılarak ilerleyen süreçte araştırmacılar tarafından değişik uygulamalar yapılabilir. Ayrıca Türkiye için önemli bir konuma sahip olan kalkınma ve yatırım bankalarının farklı yöntemlerle araştırılabileceği öngörülmektedir.

\section{Kaynakça}

Akyüz, Fatma, Ali Şevket Soba, Tolga Yeşil (2020), Katılım Bankalarının CAMELS Analizi Yöntemiyle Finansal Performanslarının Değerlendirilmesi, Muhasebe ve Finansman Dergisi, (87), s. 145-166.

Arıçelik, Gülçin (2010), Ticari Bankalarda Performans Ölçümü: CAMELS Analizine Dayalı Bir İnceleme, Yayınlanmamış Yüksek Lisans Tezi, Dokuz Eylül Üniversitesi Sosyal Bilimler Enstitüsü, İzmir.

Çinko, Murat, Emin Avcı (2008), CAMELS Dereceleme Sistemi ve Türk Ticari Bankacılık Sektöründe Başarısızlık Tahmini, BDDK Bankacılık ve Finansal Piyasalar, Cilt:2, Sayı:2, s. 25-48.

Ege, İlhan, Emre Esat Topaloğlu, Özlem Karakozak (2015). CAMELS Performans Değerleme Modeli: Türkiye'deki Mevduat Bankaları Üzerine Ampirik Bir Uygulama, Niğde Üniversitesi İktisadi ve İdari Bilimler Fakültesi Dergisi, Cilt: 8 (4), s. 109-126.

Emir, Mustafa, Gülay Çizgici Akyüz (2018), Türkiye'deki Mevduat Bankalarının Finansal Performans Değerlendirmesi: CAMELS Yaklaşımı. Karadeniz Teknik Üniversitesi Sosyal Bilimler Enstitüsü Sosyal Bilimler Dergisi, Cilt: 8 (15) , s. 7-26.

Eyceyurt Batır, Tuğba (2019), Türkiye'de Kamu Katılım Bankalarının Bankacılık Sektörü Bazında Değerlendirilmesi: CAMELS Analizi ile 2015-2017 Yıllarına İlişkin Bir İnceleme, Muhasebe ve Finansman Dergisi, (83), s. 193-212.

Gaul, Lewis, Jonathan Jones (2021). CAMELS Ratings and Their Information Content, Office of the Comptroller of the Currency the U.S. Department of the Treasury, First Version: 1/6/2021, Washington, DC 20219

Gümüş, Fatih B., Öner Nalbantoğlu (2015), Türk Bankacılık Sektörünün CAMELS Analizi Yöntemiyle 20022013 Yılları Arasında Performans Analizi, Afyon Kocatepe Üniversitesi İ̈BF Dergisi, Cilt:17(2), s. 83-106.

Kandemir, Tuğrul, Nuray Demirel Arıcı (2013), Mevduat Bankalarında CAMELS Performans Değerleme Modeli Üzerine Karşılaştırmalı Bir Çalışma (2001-2010), Süleyman Demirel Üniversitesi İktisadi ve İdari Bilimler Fakültesi Dergisi, Cilt:18 (1), s.61-87.

Karahanoğlu, İlham (2017). Türk Kalkınma ve Yatırım Bankalarının Aktif Karlılığını Etkileyen Faktörlerin Belirlenmesi, Erciyes Üniversitesi İktisadi ve İdari Bilimler Fakültesi Dergisi, Cilt: (50), s. 167-186. 
Kaygusuz, Mehmet, Behlül Ersoy, Tunga Bozdoğan (2020), CAMELS Değerlendirme Sistemiyle Bankaların Finansal Performanslarının TOPSİS Yöntemiyle Analizi, İnsan ve Toplum Bilimleri Araştırmaları Dergisi, 2020, 9 (1) s. 67-95.

Öztürk Karaçor, Zeynep, Fatih Mangır, Şevket Süreyya Kodaz, Mustafa Kartal (2018), Kamusal ve Özel Sermayeli Bankaların CAMELS Performans Analizi: Türkiye Örneği, İstanbul Gelişim Üniversitesi Sosyal Bilimler Dergisi, ICEFM 2017 Özel Sayısı, s. 47-65.

Shaddady, Ali, Tomoe Moore (2019). Investigation of the effects of financial regulation and supervision on bank stability: The application of CAMELS-DEA to quantile regressions, Journal of International Financial Markets, Institutions and Money, 2019, Volume 58, pp. 96-116

Şen, Ali, Süleyman Solak (2011). Ticari bankacılık sektörünün camels analizi: Türkiye örneği, Finans Politik ve Ekonomik Yorumlar Dergisi, 48(554), s. 51-70.

Şendurur, Utku, Fatma Temelli (2018), CAMEL Derecelendirme Modeli Yardımı İle Türkiye'de Faaliyet Gösteren Geleneksel Bankalar Ve Katılım Bankalarının Karşılaştırmalı Analizi, Ulakbilge Dergisi, Cilt: 6(23), s.525-543.

Şenel, Cemil, Sinan Şekeroğlu (2019), Yatırım ve Kalkınma Bankalarının Etkinliklerinin VZA Yöntemiyle Analizi ve Türk Bankacılık Sektöründe Bir Uygulama, Üçüncü Sektör Sosyal Ekonomi Dergisi, Cilt:54(1), s.565-580.

Uslu, Ali (2019), Türkiye'deki Yabancı Sermayeli Bankaların CAMELS Analizi ile Performanslarının Ölçümü, Muhasebe ve Finansman Dergisi, (82), s. 199-220.

Uslu, Ali, Murat Türk, Fatih Coşkun Ertaş (2019), Türkiye'deki Mevduat Bankalarının CAMELS Performans Analizi, Business \& Management Studies: An International Journal, Cilt:7, Sayı:3, Y11:2019, s.122-139.

Türkiye Bankalar Birliği (TBB) (2020). Türkiye'de Bankacılı Sistemi Seçilmiş Rasyolar 2009-2019, Rapor Kodu: YT05, İstanbul.

Türkiye Bankalar Birliği (TBB) (2021) Bankalarımız 2020, Türkiye Bankalar Birliği Yayın No:339, Mayıs 2021, İstanbul.

Wanke, Peter, Azad, Md Abdul Kalam, , Carlos Pestana Barros (2016). Financial distress and the Malaysian dual baking system: A dynamic slacks approach. Journal of Banking \& Finance, Volume 66, pp.1-18. 